\title{
Basic characteristics of Czech business entities in the context of national and international accounting
}

\author{
Lucie Meixnerová \\ Moravian University College Olomouc, \\ Crech Republic \\ Email:luciemeixnerova@seznam.cz. \\ Eva Sikorová \\ Moravian University College Olomouc, \\ Crech Republic \\ eva.sikorova@mvso.cz.
}

\begin{abstract}
The paper deals to analyze the selected accounting aspects of the micro, small and medium-sized enterprises in the Czech Republic in the context of accounting harmonization. The aim of this paper is to identify and evaluate whether there are dependencies between accounting indicators in the context of domestic and international environment by using selected methods of correlation analysis as well as the methods of analysis, synthesis and comparison are used. The paper follows the research implemented at Moravian College Olomouc in the field of small and medium-sized enterprises (Sikorová et al., 2009-13 and 2016) and the authors' own research. The evaluation of companies showed that a higher number and growth of enterprises is in enterprises with international activities. The number of companies which increasingly cooperate with foreign business entities is growing in connection with the reasons for processing financial statements according to the international form of accounting harmonization.
\end{abstract}

Received: March, 2017 1st Revision: April, 2017 Accepted: October, 2017 $10.14254 / 2071$ $8330.2017 / 10-3 / 9$

Keywords: business entity, Czech legislation, international accounting standarts, accounting harmonization.

JEL Classification: F23, M21, M41

\section{INTRODUCTION}

At the beginning of the new millennium we observe dynamic development of entrepreneurial activities and entrepreneurial accounting too, and not only in Czech Republic, but worldwide. Accounting is considered to be an integral part of enterprise economy around the world. The main reason for managing accounting is own interests of a business entity (accounting entity). That interest is a tool to evaluate the fulfilment of enterprise objectives that provides evidence concerning the management of entrusted property, success in various activities, and marketability of various types of products, goods and services. 
Accounting evaluates the effectiveness of enterprise management as well as successfulness of decisionmaking and achieved productivity rates (Sikorová, 2005). The result is the growing tendency for entrepreneurship and relatively strong differentiation between accounting systems at the level of business entities. Although entrepreneurship is currently considered a surviving phenomenon, entry to entrepreneurship is still limited by some barriers. The major problems for business entities are related to their international activities, lack of experience, of business contacts or finance financial sources. Development of entrepreneurship is of fundamental importance for individual countries, as in consequence it creates new job opportunities and new enterprises. Entrepreneurship contributes to economic growth, promotes competitiveness, creates and uses human and intellectual capital, and thus contributes to the development of regions and communities (Lukeš et al., 2007). Accounting is the process of recognition, measurement, registration and mediation of economic information that enables the users of this information to make decisions. It is the information system that displays information about the value relationships of a particular entity (accounting entity) (Landa, 2008). However, entrepreneurs are often stated to have problems due to lack of counselling, education, sharing of experience, more stable and simpler legislation, market closeness, financing, sociocultural norms and public support, especially when it comes to international activities (Lukeš, et al., 2007).

In this context, the paper focuses on the basic characteristics of Czech business entities in relation to accounting. The concept of compiling financial statements in accordance with the selected forms of accounting harmonization IAS/IFRS and Czech national accounting standards was chosen for several reasons. One of the reasons is that perceptions and approaches of business entities under different accounting standards can complicate the results of business activities. The choice of different accounting methods not only presupposes different concepts of management and enterprise activities but also affects their international activities which are complex and difficult to compare due to un-unified international data. The most important indicators are monitored in terms of their availability as well as in terms of the methods used to clarify accounting management according to national and international accounting standards including the connection of Czech business entities to international markets. The predominant field of business activity - production, trade, services or a combination of these - was determined on the basis of the survey results and was determined on the basis of the survey results and the evaluation using the correlation. The authors of this paper publish the results of their research into small and medium-sized businesses in the Czech Republic. There is only a theoretical view of Czech accounting and terminology. There is no practical perspective. Small and medium enterprises can't be used as a practical tool for evaluation and overall management for investors, shareholders or owners of the company and other readers.

The introductory part of the paper defines business entities micro, small and medium enterprises of Czech Republic as well as the form of reporting of business entities according to national and international accounting standards IAS/IFRS. The second part presents the results of the research conducted among business entities in the period of 2009-2014 and 2016. The final part of the paper evaluates the basic characteristics of Czech business entities in the context of national and international accounting legislation application.

\section{THEORETICAL FRAMEWORK}

The operation of the business entities is closely connected to accounting and reporting. It is based on the concept of the so-called Treaty of Rome (1957), the Treaty establishing the European Economic Community. Its basic aim was to create the foundations on which it would be appropriate to implement the connection of the European countries aiming to provide a common activity of the economic and social 
progress (Heyrovský, 1924). The Treaty of Rome constitutes the foundation for the harmonization of accounting and lies in overcoming the differences between individual national accounting systems. The treaty has entered into force on 1st January 1958 and the European Economic Community was created on its basis. It was followed up by the Single European Act (1986) and the Maastricht Treaty on European Union (1991) which carries out the adaptation of the legislation of the Member States through common law-directives which were incorporated into the national rules of each country of the European Union (EU). The transformation of the Czech economy from a centrally planned to a market economy is associated with a number of changes in many areas of our society. In the Czech Republic the unification of accounting begun in 1945 after the renewal of the independent Czech state. It was followed by the rationalization of accounting management in enterprises, arranging the unified data for management of the enterprise and public, creating the prerequisites for intercompany comparisons, facilitating tax and financial controls, etc.

In recent years, as a result of the change in property relations, a significant development of private entrepreneurship can be traced in the Czech Republic. A number of the Czech tax areas got closer to the tax requirements of the EU (Sikorová, 2005). An important milestone in the accounting of the Czech Republic was reached in 1993 and, starting from that year, the accounting has transformed to fulfill the objectives and needs of the market economy. At the same time, the Czech accounting system is getting closer and closer to European standards. The aim of the reform was to make an effort to ensure the comparability of accounting data at national and international levels and to adapt the accounting to the needs of management. The financial statements which are the primary source of data for the evaluation of the economic and financial situation of the enterprise have also undergone big changes. The accounting in the Czech Republic, as well as in other countries of continental Europe, is regulated through the valid legislation of the state represented by the Ministry of Finance. All changes are legislatively supported. One of the major changes valid from the 1st January 2016 is the introduction of legislative changes in the categorization of the accounting entities in the Czech Republic (Zákon o účetnictví, 2016). The categorization of an accounting unit is based on the European Union directive and its categorization (micro, small, medium and large accounting unit) is dependent on the implementation of the directive in the particular country. In accordance with the rules of the European Union (Recommendation 2003/361/EC), an enterprise is considered medium-sized if the number of employees does not exceed 250, the annual turnover EUR50 million and the annual balance sheet total EUR43 million, the classification limits for a small and micro enterprise are lower.

The operation of business entities which are one of the basic forms of the organization of the economic life of the enterprise is closely connected to accounting standards. The accounting of business entities is directly influenced by a number of important aspects: the market economy, the financial market which includes both the money market and the capital market, or alternatively the foreign exchange market and the market of precious metals, or the money (monetary) economics (Sikorová, 2005). The operation of national enterprises on the global market, mutual cooperation and development of the world economy bring the intense need for accounting harmonization. Harmonization does not mean that individual national accounting adjustments have to be completely identical, fully harmonized and addressed jointly, but they should not be logically internally contradictory. The international accounting harmonization is focused in particular on accounting (financial) statements. Czech accounting legislation relates to the accounting management which is a basis for drawing up the financial statements. By its nature, the accounting itself is the key system in the process of information and management activities of business (and non-business) entities and in related areas. In general, it belongs among the basic sources of economic information. It provides users with information on the financial situation of the enterprise and on its economic result for a given period of time. Furthermore, it increasingly evaluates the method of forecasting of the financial 
situation, or the ability and extent to which the business entity is able to achieve positive business results in future. In relation to the taxes, the orientation towards satisfying the requirements arising from the needs of the financial management of the enterprise becomes a priority (Sikorová, 2001), (Santis et al., 2016). Among the authors who have been dedicating with tax, accounting topic and international accouting for a long term, we can include Czech authors e.g. (Hinke, 2013), (Dvořáková, 2014), (Kovanicová, 2004, 2012), Kovalčíková (2008), Král (2011), (Krajňák, 2011), Široký and Stř́llková (2014), Sedláček (2005) or Valentová (2010) or from non-Czech authors (Shamrock, 2012) or (Samuel, 2011). Many other prominent experts with whom the authors participated in some of copyright publications and cooperation in professional associations and organizations. Some publications that directly affect the period under review and comparison of the current state of accounting and tax legislation provide the following overview author Sikorová (2006) or legislation of Ministry of Finance of the Czech Republic (2016) and the Union of Accountants in the Czech Republic (2016). According to available the results achieved in major foreign literatures and contributions, we can find few research about accounting harmonization of the Czech business entities.

The international integration acquiring global dimensions as well as the need for harmonization of international accounting of enterprises, especially those that are located in different countries, which need to keep accounting records and prepare reports not only to meet the demands of the country but, at the same The international integration acquiring global dimensions as well as the need for harmonization of international accounting of enterprises, especially those that are located in different countries, which need to keep accounting records and prepare reports not only to meet the demands of the country but, at the same time, to provide the necessary details of the financial position and financial performance of the whole enterprise, are becoming an important aspect in the current development of the world economy. Currently, the international harmonization of accounting is realized in the following forms:

- International Accounting Standards - IAS.

- Council Directives of the European Community.

- Generally Accepted Accounting Principles - GAAP.

Each country has a number of its accounting specifics which can cause limited comparability in the global context. The Directive of the Council of the European Community is based on the Treaty of Rome of 1957. The attempt to create the foundations on which it would be appropriate to implement the connection of the European countries with the aim to secure joint activities of the economic and social progress has become its fundamental objective. Currently, the international financial reporting standards (IFRS) and US GAAP have played an important role in the accounting harmonization. The IFRS have been selected as the instrument of accounting harmonization in Europe. Generally Accepted Accounting Principles (GAAP) have arisen and are applied, in particular, in the USA. International Accounting Standards (IAS) are importantly recommended to professional accounting organizations in individual countries. The main aim is to achieve the global harmonization of financial accounting and reporting. Due to its transparency and clarity for a wide group of foreign investors, the compilation of financial statements in accordance with the international standards is becoming not only a trend, but also a necessity. The difference between the Czech legislation concerning accounting and IAS/IFRS accounting system is the disparity in profit reporting. IAS/IFRS is not the tax-oriented accounting system, in accordance with IAS/IFRS profit is not the basis for the calculation of taxes, which means that all the facts presented in the accounting reports, according to IAS/IFRS, present the performance and financial position of the business entity as well as the determination of the value of its shares on the stock exchange (Hinke, 2013). Another difference is the cost reporting. The accounting and reporting of costs should be based on the provisions of the conceptual framework and particular standards that describe a concrete situation.. According to the 
conceptual framework of the IAS/IFRS the cost is defined as a reduction in economic profits, which reflects the loss or reduction of assets, or the increase of liabilities. Thus, this is the loss of profit which will lead to a decrease in equity by any other means than its draining by the owners (Shamrock, 2012) and (Hinke, 2013). The findings of a series of studies, for example Barth (2008) or Bartov et al. (2005), state that the financial statements compiled according to IFRS provide information of higher quality in comparison with the financial statements compiled according to national accounting regulations. If the information is compared in an international context, it is not appropriate to use financial reports compiled according to national accounting regulations. Each country has a number of its accounting specifics which can cause limited comparability in the global context. The procedure of converting financial statements compiled according to national accounting regulations to the financial statements according to IFRS is governed by IFRS 1 standard, as reported by Hakalová, Pšenková and Losová (2014). Accounting provides the basis for tax purposes. Accounting profit is transformed into the tax base, and it is then taxed at either a corporate tax (in the Czech Republic, it is the corporate income tax) or a personal pension tax (in the Czech Republic, it is the income tax of natural persons), depending on the legal form of the business. It should be noted that if the books were kept only under IFRS in the Czech Republic, according to the Income Tax Act, there would be an obligation to purge this tax base under IFRS from the effect of IFRS.

\section{RESEARCH METHODOLOGY}

The primary objective of research was to identify the current state of knowledge and use of the national or IAS/IFRS accounting standard in relation to the business activities of Czech enterprises. The research involved the analysis of basic characteristics and determination of the predominant field of activity of business entities. Due to the stated objective of the research, the method of the explorative research in the form of questionnaires was chosen. While implementing the research, the questionnaires were distributed to each of the respondents and the empirical data were collected. The questionnaires were handed in person due to their returnability. The research was conducted only among the Czech respondents; in other countries it was left out of account. The paper interprets and numerically and graphically represents the results of the research. In the research period 2009-2014 and 2016, the own survey involved a total of 350 respondents business entities from all over the country in order that all regions of the Czech Republic were represented and the sample of respondents was relevant. The selection of respondents was carried out on the basis of a pre-requisite. Considering the research aim, the basic pre-requisite for inclusion of a company into the research was: entrepreneurial subject activity in the Czech Republic and international business. The research team was collecting the data and the data collection proceeded as manual search on web portals. The primary data was acquired by collecting via the calling or visiting. The individual respondents were continuously surveyed about the changes in the period under review. Changes related to the development of their business activities in connection with a focus on accounting and overall business activities of the examined enterprises were investigated. In this context, the results obtained in the period under review were compared and the trends of development of business activities in connection to the related accounting, tax and legislative aspects as well as the legal form of entrepreneurship affecting international business activities were determined. The aim of the survey was to get expert insights on the entrepreneurial framework conditions. The individual conclusions listed in the surveys and in correlation and their subsequent evaluation are influenced by the respondents and, therefore, the following requirements affecting the overall business activity of enterprises were set out in the survey:

- the size of the examined enterprise (business entity) or accounting entity,

- the number of employees, 
- the predominant field of activity,

- the connection with foreign business entities,

- turnover of entities,

- the type of accounting the business accounting entity uses: national, international or both,

- the predominant area in terms of accounting and management of financial flows and which area is the most problematic.

In this context, the terminological explanation is important: the respondents are understood as the accounting entities, i.e. business entities. This terminological clarification is given due to the relevance of outcomes. For the same reason, the non-profit entities were abstracted from the survey as well. The financial institutions such as banks, savings banks, insurance companies, health insurance companies were also abstracted from the process of the research. When conducting the research, other abstractions were related to the legal form, which means in most cases the accounting entities with legal form of joint-stock companies and limited liability companies were represented. In addition to the survey and its evaluation, in our case, data were investigated in the following ways:

- observation (comparison with obtained results and the evaluation of the survey), linkage of theory and practice, comparison of individual entities with regard to their size (value indicators - number of employees, turnover, and other values),

- measurement (other methods used in the context of the evaluation of the use of IAS/IFRS in connection to values investigated in the survey,

- results from the secondary data were evaluated using Microsoft Office Excel and the statistical software IBM SPSS 19.

\subsection{Partial conclusions}

The research has inspired us to investigate the dependences on the size of the enterprise, number of employees, priority fields, and on the contrary, on the least recognized fields. The research also considers the other representation of relation to foreign business entities (cooperating accounting entity, percentage representation of the importance of relationship between the supplier and purchaser) as well as the percentage representation of the relationship between the parent company and subsidiary, or alternatively the co-investigator of the project, etc. and many other alternatives. According to the surveyed enterprises, the size of the examined enterprise (business entity) or accounting entity is mostly small. The survey revealed that the number of employees of the enterprise, broken down by individual groups of 0-9, 10-25, and 26100, see Figure 1, shows the largest representation in group of 10-25 employees. Specifically, division between 1-10 employees in the amount of $17 \%, 11$ to 30 employees by $28 \%$, amounting to $31-50$ employees in the amount of $21 \%$ and over 50 employees of $34 \%$. From the survey revealed that in the case link between 1-10 and 11-30 employees are the most represented firms up to 30 employees. Small enterprises represent $66 \%$ of the total number of enterprises in the Olomouc region. 


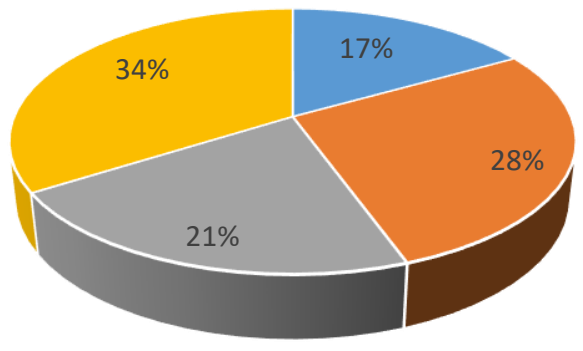

- 1 - 10 employees

- 11-30 employees

- 31-50 employees

- above 50 employees

Figure 1. Number of employees in the company

Source: Authors' calculations based on questionnaire surveys

The evaluation of the survey conducted with a sample of 68 selected business entities, Table 1 , shows the predominant activity is the trade and services represented by 16 respondents, production and trade is represented by 11 respondents, the combination of production, trade and services is represented by a total of 10 respondents.

Table 1

Predominant activity of the enterprises

\begin{tabular}{|l|c|}
\hline \multicolumn{1}{|c|}{ Predominant activity } & Number of respondents \\
\hline Production & 8 \\
\hline Trade & 10 \\
\hline Service & 12 \\
\hline Production and trade & 11 \\
\hline Trade and service & 16 \\
\hline Production, trade and service & 10 \\
\hline Summary & 68 \\
\hline
\end{tabular}

Source: Authors' calculations based on questionnaire surveys

The highest proportion of enterprises have a turnover of more than CZK 25 million / year, dealing with manufacturing or processing activity. Furthermore, the most represented businesses with a turnover of 11-25 million CZK / year, then 6-10 million CZK / year, 1 - 5 million CZK / year and businesses to one million CZK / year, Figure 2.

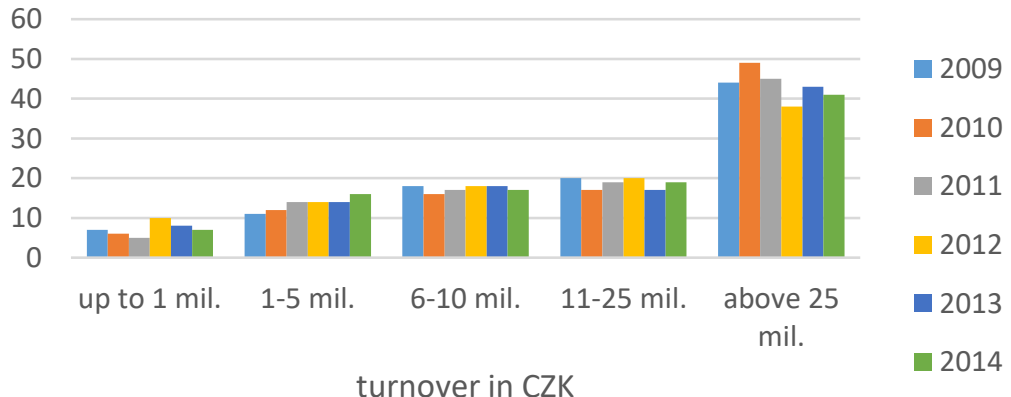

Figure 2. Turnover of business entities in years 2009 - 2014

Source: Authors' calculations based on questionnaire surveys 
The evaluation of the survey conducted with a sample of 350 selected business entities shows a growing number of enterprises characterized by a noticeable increase in cooperation with foreign business entities (suppliers, investors, purchasers) which is connected with the reasons for final accounts compilation according to the international form of accounting harmonization. Reasons for processing to prepare financial statements according to international accounting harmonization forms in the years 2009-2014 show Figure 3. As shown in Table 2, the relationships between individual variables show a moderately strong positive dependency. Subsequent analyses were conducted to further analyse and confirm these relationships. The main reason for the issue of Czech national standards lies in determination of general principles according to which a business can further utilise its own solution of a concrete accounting case. Czech accounting standards - National accounting standards do not represent a legal norm, but a recommended modification of a certain area, group of property, type of an accounting case, when a basis must be precisely defined, way of a solution or possible variant of solutions.

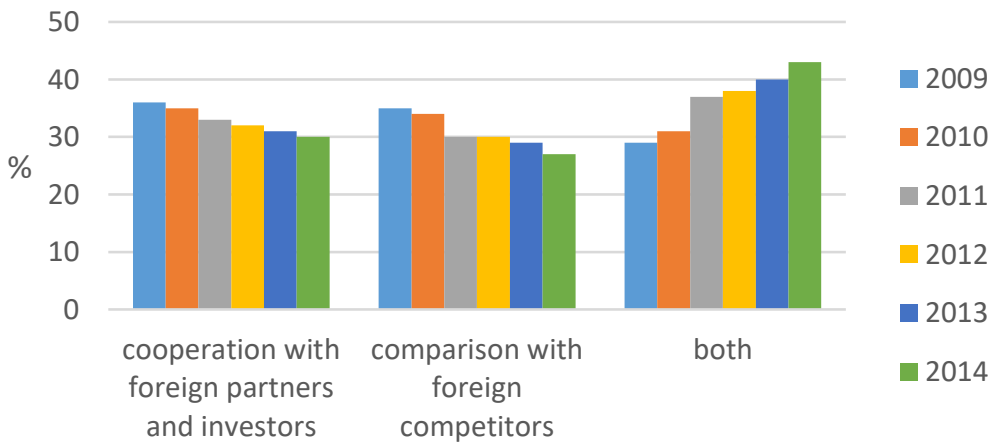

Figure 3. Reason for final accounts compilation according to one of the forms of harmonization (in years 2009 - 2014)

Source: Authors' calculations based on questionnaire surveys

In currently, the basic point is a harmonization of international accounting and taxation together with co-ordination between the particular countries of EU. The attention paid to the accounting and taxes during recent days is not accidental. The reason for final accounts compilation according to one of the forms of harmonization of accounting is mainly the cooperation with foreign partners and investors. The investigated respondents compile their final accounts according to one of the forms of harmonization only for the reasons of their own comparison to foreign competitors. A number of respondents state both the cooperation with foreign partners and investors and their own comparison to foreign competitors, Figure 4. It is a question of many facts and ongoing changes, which occurs in today's life and must be considered. Hence, the measurement and display of the financial effect of like transactions and other events must be carried out in a consistent way throughout an enterprise and over time for that enterprise and in a consistent way for different enterprises. 
Table 2

Correlation matrix of SMEs in year 2016

\begin{tabular}{|c|c|c|c|c|c|c|}
\hline & & Micro e. & Small e. & Medium e. & $\begin{array}{l}\text { Cooperation } \\
\text { with foreign } \\
\text { partners }\end{array}$ & $\begin{array}{l}\text { Cooperati } \\
\text { on with } \\
\text { foreign } \\
\text { investors }\end{array}$ \\
\hline \multirow[t]{3}{*}{ Micro e. } & $\begin{array}{l}\text { Pearson } \\
\text { Correlation }\end{array}$ & 1 &, $465(* *)$ &,$- 488(* *)$ &, $079(*)$ &, $501(* *)$ \\
\hline & Sig. (2-tailed) & . & 000 & ,003 & , 130 & ,000 \\
\hline & $\mathrm{N}$ & 350 & 350 & 350 & 350 & 350 \\
\hline \multirow[t]{3}{*}{ Small e. } & $\begin{array}{l}\text { Pearson } \\
\text { Correlation }\end{array}$ &, $465(* *)$ & 1 &, $501(* *)$ &, $498(* *)$ & ,462(**) \\
\hline & Sig. (2-tailed) & ,000 & . & 000 & ,000 & ,000 \\
\hline & $\mathrm{N}$ & 350 & 350 & 350 & 350 & 350 \\
\hline \multirow[t]{3}{*}{ Medium e. } & $\begin{array}{l}\text { Pearson } \\
\text { Correlation }\end{array}$ &,$- 488(* *)$ &, $501(* *)$ & 1 &,$- 255(* *)$ &, $632(* *)$ \\
\hline & Sig. (2-tailed) & ,003 & ,000 & . & ,000 & ,000 \\
\hline & $\mathrm{N}$ & 350 & 350 & 350 & 350 & 350 \\
\hline \multirow[t]{3}{*}{$\begin{array}{l}\text { Cooperation with } \\
\text { foreign partners }\end{array}$} & $\begin{array}{l}\text { Pearson } \\
\text { Correlation }\end{array}$ &, $079(*)$ &, $498(* *)$ &,$- 255(* *)$ & 1 &,- 044 \\
\hline & Sig. (2-tailed) & , 130 & ,000 & ,000 & . & , 170 \\
\hline & $\mathrm{N}$ & 350 & 350 & 350 & 146 & 350 \\
\hline \multirow[t]{3}{*}{$\begin{array}{l}\text { Cooperation with } \\
\text { foreign investors }\end{array}$} & $\begin{array}{l}\text { Pearson } \\
\text { Correlation }\end{array}$ &, $501(* *)$ & ,462(**) &, $632(* *)$ &,- 044 & 1 \\
\hline & Sig. (2-tailed) & ,000 & ,000 & 000 & , 170 & \\
\hline & $\mathrm{N}$ & 350 & 350 & 350 & 350 & 350 \\
\hline
\end{tabular}

Source: Authors' calculations based on questionnaire surveys

** Correlation is significant at the 0.01 level (2-tailed).

$*$ Correlation is significant at the 0.05 level (2-tailed).

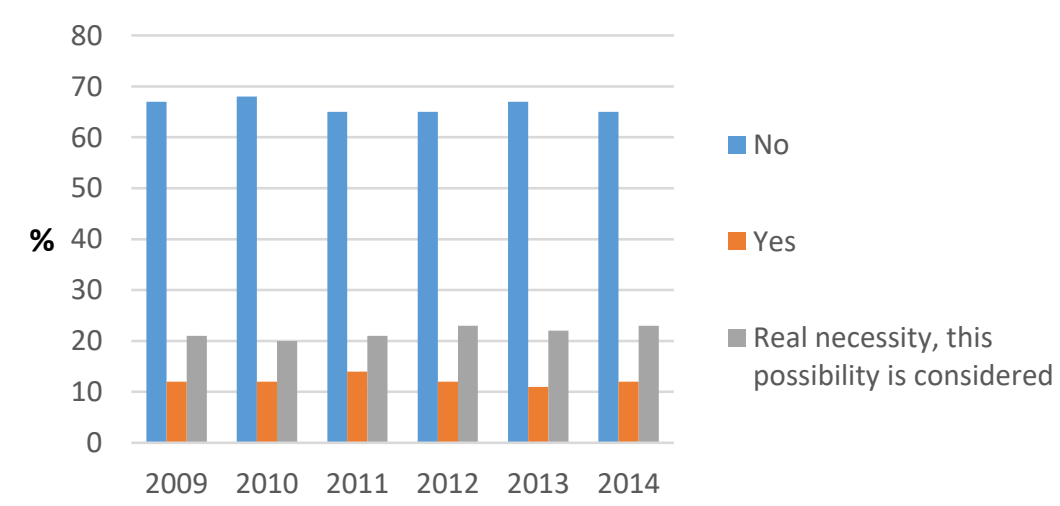

Figure 4. Necessity to compile final accounts according to one of the forms of harmonization of accounting in years 2009-2014

Source: Authors' calculations based on questionnaire surveys

The tax and related laws are also a considerable problem which substantially affect financial accounting and reporting. The outstanding issues remain in the area of accounting methodology, but they can be solved 
by using the International Accounting Standards. The sample of business entities determined the receivables, costs and revenues as the predominant area of their accounting with regard to the most problematic areas which are the long-term assets, financial assets and time differentiation, Figure 5.

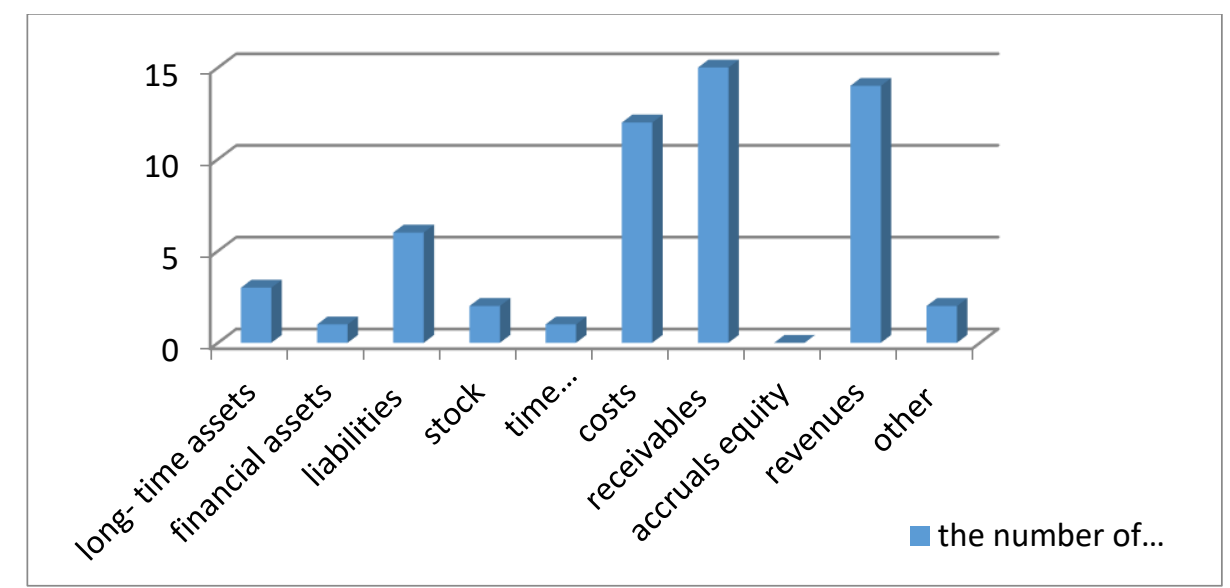

Figure 5. Predominant area of accounting of the enterprise

Source: Authors' calculations based on questionnaire surveys

The results of correlation analysis in Table 3 in the year 2016 show that there is there is a strong degree of dependence among the indicators of accounting (liabilities, receivables, own capital), since the value of the coefficient $r$ is equal to 0.75 . One of the reasons is the long-term company operation in the international environment. Companies must be not only reasonably profitable, but they must be able to reconcile their needs, i.e. bind capital in short-term parts of assets that must be paid by costs associated with their funding and also must seek financial structure with minimal costs of capital, both their own and foreign capital. The low level of financing by the long-term resources and subsequent high interfirm indebtedness of companies are referred to as one of the serious problems of companies. Compliance with the use of foreign capital for financing the asset part should always correspond to the degree of company's liquidity and financing rules that significantly affect profitability. Other influences that affect the asset and capital structure are: the cost of capital, inventories, accounts receivable, interest, taxes, liquidity, dividend policy, risk, etc., these are absent from the paper. Strong dependency of liabilities, receivables, own capital indicators points to negatice capital appreciation, many companies use own capital.

Table 3

Comparison of profitability indicators

\begin{tabular}{|l|c|c|c|}
\hline & Liabilities & Receivables & Own capital \\
\hline Liabilities & 1 & & \\
\hline Receivables & 0.4123 & 1 & \\
\hline Own capital & 0.7936 & 0.7856 & 1 \\
\hline
\end{tabular}

Source: Authors' calculations based on questionnaire surveys

The research also shows in overcoming existing differences among particular national accounting systems. The Czech Republic, supposing the integration in the world economy (as well as the European Union), has to reconcile with such a development too. Therefore, wide specialist community should be interested not only in the knowledge of a Czech accounting modification but also the problems of an 
international accounting harmonization and the concurrently used transnational and national business economic information systems which enable the reporting of Czech accounting to the international one, namely EIS, the software application SAP, K2, NAVISION, ORACLE, TESCO SW. The examples of transformation for selected respondents are supplemented by the practical application of reporting as well as the arising individual variant solutions.

\section{DISCUSSION}

In addition to the knowledge of local accounting regulations, international accounting harmonization also becomes a problem. Currently, each country has its own system of accounting regulation. Differences in regulations, tax systems or, as Dewing et al. (2008) mention, differences in the impact of accounting and tax professions represent factors that caused differences in financial reporting.

In the research evaluation, it was found out that the number of companies in which there are reasons for processing financial statements according to international form of accounting harmonization is increasing, since financial reports provide important information in the field of company management, Figure 6. The reason for compiling financial statements according to one of the forms of accounting harmonization is the cooperation with foreign partners and investors or the need to be compared to foreign competition. Our own research confirms that $65 \%$ of companies on average use some of the forms of international standards (US GAAP or IFRS). Bartov et al. (2008) state that the financial statement compiled in accordance with IFRS provides better information than just financial statement compiled according to national accounting regulations. Problems with international accounting standards appear on average in 35 $\%$ of companies and are particularly influenced by the lack of information, education, training and international business with foreign partners or customers. Table 4 confirms the weak dependence among accounting indicators. It confirms the trend of development and increasing role of accounting harmonization due to the global nature of economy and the development of international entrepreneurship. The IFRS task is to ensure that the information obtained from accounting is comparable and understandable for all their users. In recent years, it has been compulsory for a large number of to compile their financial statements according to IFRS (Christensen et al. 2013). The choice of accounting and the system which will be used to compile the financial statement is given by the activities and needs of both the company and market. The Czech accounting is gradually approaching the trend of accounting harmonization development (international financial reporting standards). Krajñák (2015) states that the advantage of IFRS is their globality, a higher degree of clarity, comparability and relevance in comparison with national accounting standards. The Czech accounting is approaching towards the IFRS system also by implementing the provisions of the Directive 2013/34/EU and adopting the updated Act No. 563/1991 Coll. on Accounting valid from 1st January 2016 according to the directives of the European Union.

The results of correlation analysis described in Table 4 indicate that there is a medium degree in year 2016 of dependence between the compilation of the financial statement according to Czech accounting standards and according to IFRS, since the value of the coefficient $r$ is equal to 0.3. One of the reasons can be the fact that the profit or loss found in accounting and then adjusted becomes the basis for calculating the tax liability. The Income Tax Act states that the profit or loss needs to be purged from the IFRS influence when being transformed to the tax base. In this case, there are disadvantages such as high input costs associated with the initial IFRS application, as well as the costs associated with keeping two types of books. In comparison with the Czech accounting standards, IFRS focus to a large extent on outputs of accounting - financial statements. IFRSS do not strictly regulate accounting procedures, since each accounting unit can define its own chart of accounts and choose such procedures due to which it will get a true and fair picture. 


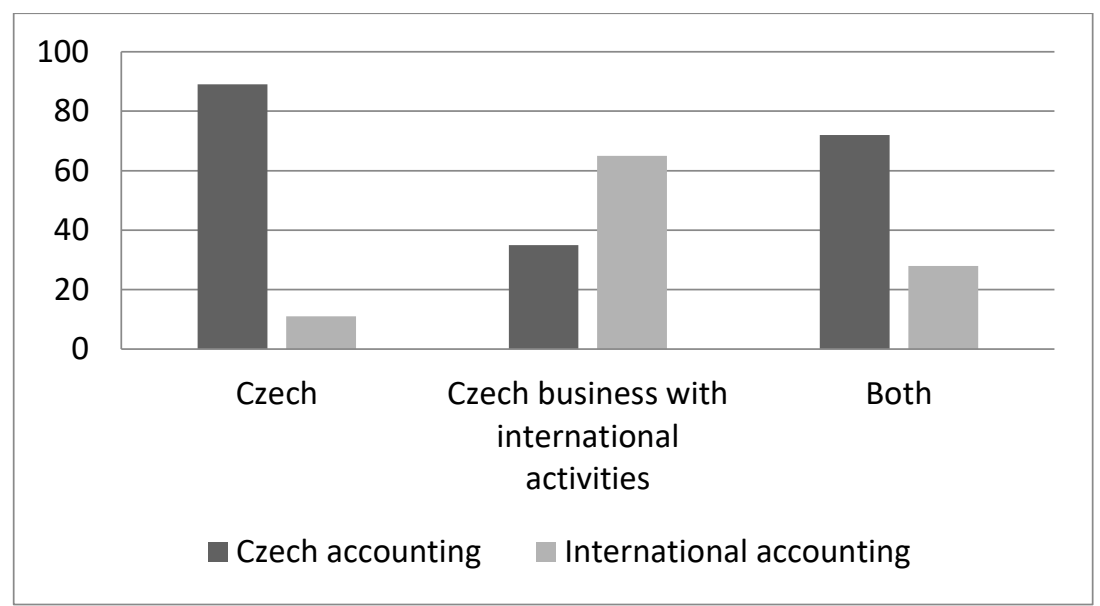

Figure 6. Comparison of compiling the financial statement according to some of the forms of accounting harmonization

Source: Authors' calculations based on questionnaire surveys

Table 4

Correlation

\begin{tabular}{|l|c|c|c|}
\hline & Czech & International & Both \\
\hline Czech & 1 & & \\
\hline International & 0.3345 & 1 & \\
\hline Both & 0.3483 & 1 & 1 \\
\hline
\end{tabular}

Source: Authors' calculations based on questionnaire surveys

\section{CONCLUSIONS}

The objective of the paper was to analyze the selected accounting aspects of the micro, small and medium-sized enterprises in the Czech Republic in the context of accounting harmonization. The evaluation of companies showed that a higher number and growth of enterprises is in enterprises with international activities. The number of companies which increasingly cooperate with foreign business entities (suppliers, investors, customers) is growing in connection with the reasons for processing financial statements according to the international form of accounting harmonization. A sample of $35 \%$ of companies does not process reports according to any different accounting system than national, 65\% confirmed reporting using a form of global standards (US GAAP or IFRS). The process of accounting harmonization lies in overcoming the existing differences between national accounting standards. The Czech Republic and all other countries must also come to terms with this development in order to get integrated into the global economy. The reason for this are the benefits of international cooperation and company development. The growing influence of international environment on business entities is thus confirmed. Unresolved questions still remain in the field of tax and related laws which substantially affect financial accounting and reporting. These are not included in this paper.

Our own research shows that the business entities use some form of International Accounting Standards is growing. The characteristics of the field of business activity of enterprises show that 16 of the business entities specialize predominantly in trade and services. International Accounting Standards emerge for $65 \%$ of business entities and problems are particularly affected by the lack of information, education 
and training. Therefore, it is necessary to support the advisory, regional or higher education centers of informational and educational support, or other institutions which help to acquire the knowledge. The accounting harmonization process, therefore, lies in overcoming the existing differences between various national accounting systems. In seeking to integrate into the global economy, the Czech Republic has to also come to terms with this evolution. Besides the knowledge of the Czech accounting adjustments, the issue of international harmonization of accounting has to become of the interest of general public. The Czech accounting moved forward by adopting a new Act on accounting, based on the directives of the European Union, thereby it approached the International Accounting Standards. The need for harmonization of accounting is the result of the internationalization of the economy of free movement of goods, services and capital. For continental Europe, the starting point becomes the official trade legislation with a number of individual regulations. The interpretation of binding regulations is determinative. The area of accounting, as a part of the financial management, is an important part of the management of the whole enterprise. Therefore, it is necessary to pay attention not only to national accounting standards, but also to the International Accounting Standards which perform a determinative role in entrepreneurship development, international cooperation, and activities as well as lead to the long-term growth and development of the business entity.

\section{REFERENCES}

Barth, E. M. (2008). International Accounting Standards and Accounting Quality. Journal of Accounting Research, 46(3), 467-498. doi: http://dx.doi.org/10.1111/j.1475-679X.2008.00287.x.

Bartov, E., Goldberg, S.R., \& Kim, M. (2005). Comparative Value Relevance among German, U.S., and International Accounting Standards: A German Stock Market Perspective. Journal of Accounting, Auditing and Finance, 20(2), 95119. doi: http://dx.doi.org/10.1177/0148558X0502000201.

Dewing, I., \& Peter, O.R. (2008). Financial Integration in the EU: the First Phase of EU Endorsement of International Accounting Standards. Journal of Common Market Studies, 46(2), 243-264. doi: http://dx.doi.org/10.1111/j.14685965.2007.00776.x.

Hinke, J. (2013). LAS/IFRS a hodnoceni výkonnosti podniku. Praha: Alfa nakladatelství.

Hakalová, J., Pšenková, Y., \& Losová, M. (2014). First-time Adoption of International Financial Reporting Standards for Business Corporations Based in EU Member State that Are Issuers of Securities Admitted to Trading on Regulated Market. 2nd International Conference on European Integration, 192-201.

Heyrovský, L. (1924). Dëjiny a systém soukromébo práva rímského. Praha: J. Otto.

Dvořáková, D. (2014). Finanční úcetnictví a výkaz̧nictví podle mezinárodních standardů IFRS. Brno: Computer Press.

Christensen, B. H., et al. (2013). Mandatory IFRS Reporting and Changes in Enforcement. Journal Of Accounting \& Economics, 56(2), 147-177. http://dx.doi.org/10.1016/i.jacceco.2013.10.007.

Landa, M. (2008). Jak rüst finanční výkasy. Brno: Computer Press.

Lukeš, M., \& Jakl, M. (2007). Podnikání v České republice. Praha: nakladatelství Oeconomica.

Kovalčíková, A. (2008). Vykazovanie informácií o rozpočte v účtovnej závierke. Zbornik konferencie AIES A 2008.

Kovanicová, D. (2004). Jak porozumět světovým, evropským, českým úcétním výkazưm. Praha: Bova Polygon.

Kovanicová, D. (2012). Abeceda úcetních znalostí pro kaz̃débo. Praha: Bova Polygon.

Krajňák, M. (2011). IAS/IFRS as One of the Tools of Accounting Harmonization in the European Union. Proceedings of the 2nd International conference on European Integration 2014 (ICEI 2014), 372-381. WOS:000346144900041

Krajňák, M. (2015). Implementation of Analytic Hierarchy Process Method in Decision-Making on the Choice of Accounting between National Accounting Standards and International Financial Reporting Standards. Journal of Applied Economic Sciences, 10(7), 1060-1075.

Král, B. (2011). Management accounting role in performance management. Finance and the performance of firms in science, education, and practice, 280-293. WOS:000306544000026 
Ministry of Finance of the Czech Republic. (2016). Accounting standards. Retrieved from: http://www.mfcr.cz/en/search?q=accounting+standarts.

Samuel, J. (2011). International accounting standards, IAS, in Europe and USA - differences and similarities. International Conference on Current Issues in Management of Business and Society Development, Latvia, 638-642. WOS:000343720900063.

Santis, P., Albuquerque, A., \& Lizarelli, F. (2016). Do Sustainable Companies Have a Better Financial Performance? A Study on Brazilian Public Companies. Journal of Cleaner Production, 133, 735-745. http://dx.doi.org/10.1016/i.jclepro.2016.05.180.

Shamrock, S. (2012). IFRS and US GAAP. New Jersey: John Wiley \& Sons.

Sedláček, J. (2005). Účetnictví pro manažery. Praha: Grada Publishing, a.s.

Sikorová, E. (2005). Ceské úcetni standardy s komentárem. Brno: CP Books.

Sikorová, E. (2006). Mzdové účetnictví 2006. Brno: Computer Press.

Sikorová, E. (2001). Praktická príručka pro podnikatele v oblasti úcetnictví a daní. Karviná: OPF SLU.

Široký, J., \& Střilková, R. (2014). Changes in the VAT Burden on Expenses of a Selected Household in the Czech Republic (2007-2012). Proceedings of the 19th International Conference: Theoretical and Practical Aspects of Public Finance 2014, 296-305. WOS:000348877900032

Union of Accountants in the Czech Republic. (2016). Retrieved from: http://www.svaz-ucetnich.eu/index en.php.

Valentová, I. (2010). Korporátní daň členských států unie z pohledu firemních investorů. Economics Management Innovation, 2(1), 71-81.

Zákon o účetnictví. (2016). Novela ₹ákona č. 221/2015 Sb., o účetnictví, ve znèni pozdèjš̌ch prèdpisů. 